\title{
Architects and the Architectural Profession in the Turkish Context
}

\section{Tahire Erman , Burçak Altay \& Can Altay}

To cite this article: Tahire Erman , Burçak Altay \& Can Altay (2004) Architects and the Architectural Profession in the Turkish Context, Journal of Architectural Education, 58:2, 46-53, DOI: $10.1162 / 1046488042485394$

To link to this article: https://doi.org/10.1162/1046488042485394

$$
\text { 曲 Published online: } 05 \text { Mar } 2013 .
$$

Submit your article to this journal

Џ Article views: 36

Citing articles: 2 View citing articles 5 
TAHIRE ERMAN

BURÇAK ALTAY

CAN ALTAY

Bilkent University

\section{Architects and the}

Architectural Profession in the Turkish Context

\section{This article explores the social construction of the architectural profession in the Turkish context} from a historical perspective. It investigates architects' views regarding their roles in society and their positions vis-à-vis their clients and users. The data from in-depth interviews conducted with twentyfour practicing architects demonstrate that both traces of elitism and the tendency to define their professional roles to affect people's lives through their designs have prevailed in architects' beliefs and actions to varying degrees.

\section{Introduction}

Education and professional discourse are two major factors that shape professionals' positions with respect to their clients. Architectural education, which is oriented towards training for creativity and ideas, and hence for individuality and self-assertion, tends to foster patronizing attitudes and arrogance. Architectural discourse, as in any professional discourse, grants architects the privilege of specialized (formal) knowledge/expertise, and supports exclusivity. ${ }^{2}$ On the other hand, architects are vulnerable to their clients because they need clients for their practices. Even architectural elites need clients because they have to produce built exemplars as the canon of architecture, which are important in forming architectural discourse. ${ }^{3}$ Relations between architects and their clients and users are embedded in the specific characteristics - social, political, economic - of a society, and this, in turn, is important in shaping architects' attitudes toward them. ${ }^{4}$ In contrast to Western societies in which capitalist and democratic developments emerged as the result of their own historical conditions, in peripheral capitalist societies, the state played the leading role in the modernization of society, taking on the role of nation-building (social engineering). In this process, professional elites and intellectuals were given the role of educating the masses into "civilized," "cultured," and "modern" ways of life. And the power/authority conferred on architects by their profession increases when they are defined as the educators of society and when paternalistic and elitist approaches to ordinary people are promoted. The power of architects may be contested by emerging actors and ideologies, however, as these societies integrate into the capitalist system, albeit in an asymmetric way, and their state-centered modernization discourse loses its hegemony. The following section elaborates on the architectural profession in the Turkish context by referring to the social, political, and economic conditions of that society in different time periods.

\section{The Architectural Profession in the 1923-1946 Period}

In this period, the professional identity of architects was that of "trainer" in the Modernization Project. The Turkish Modernization Project was a top-down elitist project ("modernization from above") carried out by the bureaucratic and military elites following the establishment of the Republic in 1923. ${ }^{5}$ During this period, the statist Republican People's party governed the society. The motto of the time was "For people, in spite of people." In the process of building a nation-state out of the remnants of the Ottoman Empire, it aimed at the modernization and Westernization of society, without losing its antiimperialist stance. ${ }^{6}$ The idea that people should learn how to live modern lives and how to be modern citizens dominated the project, and design and planning were seen as effective means in the process of creating a modern way of life. For example, in the case of villagers, it meant "introduc[ing] beds to those who are used to sleeping together on earthen floors, teach[ing] those who sit on the floor how to use chairs, provid[ing] tables for those who eat on the floor, hence revolutioniz[ing] lifestyles."7 In this context, "[modern architecture] was primarily a form of 'visible politics' or 'civilizing mission' that accompanied official programs of modernization, imposed from above and implemented by the bureaucratic and professional elites of paternalistic nation-states." 8 Modern buildings and cities of the newly founded Turkish Republic would be the arenas in which people would be acculturated into modern behavior and modern appearance. In this picture, intellectuals were given the mission of enlightening the public in the race of catching up with civilization (that is, Western civilization); intellectuals were seen as the civilizing agents of society. Architects, along with teachers, were especially important as these quotations demonstrate: "Someone who represents a vivid model of civilization, whose work becomes the mirror of civilization, this is the architect;" " "the architect as a 'cultural leader' or an 'agent of civilization' with a passionate sense of mission to dissociate the Republic from an Ottoman and Islamic past."10 Scientific claims of the emerging architectural profession, legitimized by the positivistic tenets of the Republican modernization project, granted architects much credibility and authority. They were expected both to create aesthetic buildings to modern taste and to teach people to understand and admire these modern aesthetics. ${ }^{11}$ They would set an example for the common people and train them through their built projects. Especially when contemporary/modern living meant living in apartments as nuclear families instead of in single-family houses as extended fami- 
lies, architects, through their designs, became the molders of a such lifestyle. ${ }^{12}$ They were given the role of designing the modern home. In it, the guestroom would not exist, and the kitchen would be small and organized like a laboratory. On the other hand, the salon, where the family would spend much of its time, would be furnished with modern furniture and appliances, including a piano. ${ }^{13}$ And the bathroom would be spacious, putting an end to the habit of going to public baths in the neighborhood. However, this top-down approach of the Republican elite led to "its (the modernist architecture of the house/dwelling) popular perception as 'alien' and 'imposed.' "14 Furthermore, the society largely remained outside of architectural profession. Those who lived in rural settings and towns in Anatolia continued to have their houses built mostly by local craftsmen or sometimes by the people themselves. The poverty in the era limited the practice of residential architecture to "a handful of villas and urban apartments for the Republican elite."15

In addition to their role in shaping the lives of people in the private sphere through designing the modern home, the architects of the time were expected to design public/official buildings that would reflect the ideals of the Republic and the authority of the newly founded modern nation state, as well as new building types, such as museums, theaters, and schools. The state was the primary employer of architects, which was a major reason for the absence of an autonomous professional discourse that differed from the state's ideology.

\section{The Architectural Profession from 1950 to 1980}

As a result of the multiparty system that was adopted in 1946, and the coming to office of the Democratic party that favored a liberal economy, jobs available to architects and their social roles diversified. The foreign aid to Turkey, particularly through the Marshall Plan, brought economic dynamism to society. The growing construction market led by the private sector created new job opportuni- ties for architects, challenging the monopoly of the state. This had the potential of both bringing some autonomy to architects and making them more responsive to people's desires and preferences. They were not merely in the service of the state any more, and they were not the trainers (modernizers) of society as they were in the earlier period when they had the power and legitimacy to impose designs on people in the hope of creating the modern way of life.

Another significant phenomenon that occurred in the 1950s was massive rural-to-urban migration and rapid urbanization as a result of which emerged a new type of housing (squatter housing) and a new group of people, rural migrants, in the cities. The encounter of modern urban elites with rural masses in the urban context created a strong reaction in city elites, including architects, who attempted to explain it as the peasantization of cities. Architects and urban designers were concerned about what they called "the invasion of cities," and the threat it posed to the ideal of planned cities, a required feature of modernization. The case of Ankara was particularly alarming to them. As the capital city of the new republic, Ankara was envisioned as the model of a modern, planned city. Yet it was getting out of their control when migrants kept on building their squatter houses on unoccupied land, usually on the outskirts of the city. However, they largely failed to control this phenomenon, and their action could not go beyond mere complaints. They were primarily concerned about "retain(ing) their professional monopoly and to ensure their elitist, urban identity."16

As a response to the increasing urban population, the 1965 Condominium Act was passed to permit the individual ownership of apartments. This brought a new type of building production: smallscale developers (müteahhits) began to construct apartment buildings, buying the land from the owner in return for several apartments in the building and keeping the rest of the apartments to sell mostly during the construction process. When the state gave priority to industry in its economic development model and left the housing sector entirely to market forces, it was these müteahhits who dominated the sector by their ability to build with a low level of initial capital. ${ }^{17}$

The failure of the Democratic party to keep its promises of a wealthy and democratic society ended with military intervention in May 1960. The military coup dissolved itself in a year upon the preparation of a new constitution, thus creating a suitable ground for the civil society to organize itself. This liberal political atmosphere, along with the civil rights movement in the United States, produced a strong leftist ideology among intellectuals, which also affected the social definition of the role of architects. Architects defined themselves not merely as professionals whose major task was to design and produce buildings, but also as those who were responsible for society beyond the limits of their profession. This responsibility meant concern for the social, political, and economic problems of their society, calling attention to inequalities and making people realize the exploitative nature of the capitalist system. In this respect, they were expected to act as agents to raise consciousness. ${ }^{18}$ Bozdoğan talks about the shifting orientation of architects from the West to the Third World:

Throughout the 1960s and 1970s, intellectuals and the highly politicized Chamber of Architects leaned toward Third World-ist versions of modernization, looking no longer at the West but at squatter houses and folk architecture and shifting their emphasis from the aesthetics of architecture to the politics of production processes. ${ }^{19}$

The domination of the leftist ideology among intellectuals in the 1970s also brought new ideas about the design process. Especially the graduates of progressive architecture schools were attracted to the idea of participatory design, which they regarded as a democratic way of granting people 
power in decision making in the design of buildings and environments they would use. ${ }^{20}$ This not only complied with the ideals they believed in (such as equality and distribution of power), but it also made them pioneers in the architectural practice of the time, something for which they were trained throughout their university education. The interest in participatory design was carried over to the early 1980s. In 1982, a whole issue of Mimarlık, the periodical published by the Chamber of Architects, was devoted to participation in the design process. ${ }^{21}$

\section{The Architectural Profession in the Post- 1980 Period}

The polarization of society, which led to the violent fights between the radical left and the ultranationalist right, and the economic crisis in the 1970s paved the way to another military intervention in September 1980. This military coup remained in power until 1983, and meanwhile a conservative constitution was prepared. Setting strict limits to political activities and civil society formations, it aimed to quiet social dissent. The 1980s were also the years during which neoliberal economic policies were implemented by the Özal government in the process of economic restructuring that favored privatization, foreign trade, and integration into the world capitalist economy. As a result, in metropolitan cities, and especially in Istanbul, the cityscape began to change, as office complexes, business centers, branches of multinational companies, five-star hotels, and shopping malls were built. In this process, big construction firms began to commission architects, thus becoming their major clients and replacing the role of the state, which used to organize architectural competitions for public buildings. The National Housing and Investment Administration was established in 1984, and it played a significant role in promoting big construction firms to emerge as another force in the national housing market. Moreover, foreign construction companies and architects, especially American ones, were favored for development, and large Turkish firms began to work increasingly with them.

In the depolitized atmosphere of the 1980s, architects went through a process of contesting the boundaries of architecture as a profession, trying to redefine their roles. Some insisted on the social responsibility aspect of any profession, and particularly that of architects. On the other hand, some others, in their concern for the danger of putting the profession at the service of an ideology (they meant the leftist/Marxist ideology), argued for limiting architects' roles to offering professional knowledge and expertise. Today, we observe that the "architectural profession is retreating to its more conventional preoccupation with form making, surrendering any larger mission of transforming society." 22

In the mid-1980s, a number of laws regarding squatter housing passed, which aimed at its integration into the formal housing sector by legalizing its presence and permitting up to four stories in the buildings to replace squatter houses. As a result, the squatter land became a much valued commodity, and the apartmentization of squatter houses by the müteahhits sped up, contributing to the growth of a new type of client in the construction sector, namely, squatter owners. Squatter owners' receiving several apartments in return for their squatter houses was not approved, especially by the people living modest lives in the apartments they rented; many of them were civil servants. They complained that they could not own apartments despite their being hard-working and law-abiding citizens, whereas squatter owners, who broke the law from the very beginning by building houses illegally on land they did not own, could own apartments quickly and effortlessly. Thus, this group of new clients was criticized for their wealth that they did not deserve. ${ }^{23}$ The growth of a new wealthy group in society (Özal's rich people of rural origin) who benefited from the liberal economic policies of the post-1980s contributed to this negative view of the undeserving rich, which implied not only those who became very rich too quickly, sometimes even using illegal means, but also those who lacked culture and manners. On the other hand, wealth was becoming the new social value to be glorified; money rather than culture and education was becoming the most valued social asset. The nouveau riche of the 1980s was the new agent of power, and they were the potential clients of architects.

In preparing the following section, we focus on the field study that investigated architects' positions vis-à-vis their clients and users. In the field study, in-depth interviews with twenty-four practicing architects who run offices in Ankara, the capital city, were conducted between December 1999 and February $2000 .{ }^{24}$ We analyze and interpret their responses, and while doing so we frequently use direct quotations to present the issues in the architects' own words so that their relationship with their clients and users can be better understood. We quote those responses that present vividly or summarize well the ideas mentioned in the interviews, and we italicized those words and phrases that reveal respondents' feelings about, and approaches to, their clients and users.

\section{Architects' Expert Advice versus Responding to Users and Clients}

An approach to the role of the architect in the design process that emphasized the architect's authority and expertise prevailed in the first category of architects (seven respondents). Most of them were over sixty years of age, and they had spent long years in the practice of architecture. One of them said, "It is like when a doctor prescribes medicine. The patient should strictly follow it. If the doctor tells him to take one pill every day, and he takes it in every hour, his life is in danger. It is the same in the case of architecture." Another one complained about a false understanding of democracy in society, that is, everyone is equal to everyone else, which, according to him, failed to respect specialized knowledge. 
Based on their view of the elitist professional identity of architects, they expected that others would respect their ideas and appreciate their designs, and this went hand in hand with their frustration and anger under the present conditions. They felt contempt for their clients when clients failed to acknowledge their expertise:

They think that the design process is simple, that they can design and decorate their houses. ... You almost beg your client to use your expertise, but he goes out and talks to some Ahmet or Mehmet, and prefers his ideas over yours.

They expressed benevolent intentions for deciding for their clients. For example, they wanted to create homes in which people would live happy lives. And they became frustrated when they thought that clients failed to appreciate the architect's professional capacity to improve their lives:

In my 35 years of profession, nobody ever came to me, saying, "I want to change my life, I want a different house. I love my wife, but I cannot express it. I need spaces that will help me express my emotions." People come to me asking for three rooms and a salon. They want stupid things, such as a large kitchen or pink walls. As architects, we are the people who can make it possible for others to be happy and hopeful for the future. I fantasize that he will make love to his wife, or his lover, and I design accordingly. I don't design a can-like small bedroom. I think of his happiness, his emotions. But no, he doesn't care.

Müteahhits emerged as a constant source of trouble for the architects in the field study in general. This older category of architects, in particular, expressed strong feelings of resentment and hostility for müteahhits, who were regarded as uncultured and ignorant, yet who had the power to challenge their expertise and professional authority. According to one architect,

When he started to draw a crooked sketch, trying to explain [to] me what an apartment hotel should be like, I took the pen from him, and said, "You better limit explaining your ideas in words. I am the one here who could draw." This is because of lack of culture, my dear. Turkey is the single country in which 90 percent of all the buildings are built by müteahhits, and architects have to work with them."

On the other hand, those architects who worked for big construction firms mentioned a satisfactory relationship with their clients.

Those who had money but not "culture" (the nouveau riche of the 1980s) were another source of complaint. For example, a well-known architect complained about their poor taste and vulgar manners:

These people have lost their values, their culture. You design the balcony so that they will sit down, drinking tea and enjoying the sunset. But they store car tires in their balconies instead. ... They are brutal to their buildings; they are barbarians. They install airconditioning units in their balconies without a second thought. I always say that buildings are not toys that we give to adults to play. And definitely not to those who did not have toys in their childhood and who are not used to playing with them, who can break them easily.

He continued, complaining about their interest in showing off their wealth:

Among them there are doctors who are dressed properly, who take a shower every day, who have spent a couple of years in the United States. They think they know everything. They have lost their natural being. They are our biggest enemies because the house image they have is polluted. They want houses that they see in House Beautiful, or they want houses like the ones they saw when they lived in America because they are show-offs. I don't give them a shit.

Interestingly, the same architect was sympathetic when he talked about common people (halk in Turkish) who, he thought, were natural and sweet. They had preserved their traditional values and were not alienated from their needs.

In brief, the architects in this category were quite patronizing and elitist in positioning themselves vis-à-vis their clients; they were concerned about their distinction from laypersons. They commanded authority in the design process while deciding the residential environment of their clients. They tended to perceive their clients as inferior in terms of their "culture" (taste, manners, and even a particular way of life) yet as increasingly powerful. This was especially true when clients were the nouevau riche, largely a product of the liberal period of the 1980s, and müteahhits, who have been dominating the housing market for many years. And, when the authority and cultural superiority they claimed was disputed by clients, they resented it very much.

On the other hand, the second category of architects (seventeen respondents) expressed the need to respond to the demands and preferences of users and clients for several reasons. First, some architects felt the obligation to design according to clients' demands due to their economic dependency on clients, especially when it was the client who directly commissioned the architect. This usually made them compromise their designs, which they later resented. A woman in her forties, who had a master's degree, said, "They insisted on arched windows and doors, and sincerely speaking, I had to do it. I feel frustrated every time I see that building. But what can you do? The client is the boss." The increasing difficulty of finding design projects due to the rapidly increasing number of practicing architects was eroding the bargaining power of archi- 
tects. As a result, sometimes they not only had to compromise their designs but also the type of their clients. When they did not have the power to choose their clients, they felt they were defeated: "We failed to raise consciousness in people. We could not make them understand the worth of the beautiful. Today everywhere is full of the products of those architects who gave in to clients' wishes."

A second reason for responding to clients and users were architects' personal experiences in which they had come to understand that they would not be able to make people live differently by their designs. As such, they had to learn to accept people's preferences and design accordingly. One of them said, "If I know that, whatever I do, they (rural migrants) will leave their shoes outside the entrance door, then what I should do is to design a space for shoes outside the apartment so that they will not be in the way, causing people to trip over."

A woman architect furthermore emphasized the need to design according to the habits and preferences of clients and users because "If we don't, they will try to solve the problem on their own. We should not let this happen. The outcome would be much worse if we did." Another woman architect, who, in her experiences with her clients, had come to believe that radical solutions and forced decisions are of no use, questioned to what extent architects could play a role in guiding society and directing their designs.

However, some of the architects in this category had not completely given up on the idea of making a difference in people's lives through their designs:

It may sound too strong, but I put some details in the project that will improve people's life styles, that will train them. For example, I know that they may not use the bathtub because they are used to the kurna (traditional bathtub). But I wouldn't put the kurna because I don't want to encourage such behavior. Then what I do is to reserve a space in the bathroom that could also be used for the kurna if worse comes to worse.

The third reason for architects to be concerned with accommodating clients' preferences and demands in their designs is their professional ethics, inspired by democratic values, which is against imposing one's own ideas and decisions on others. This is seen in the following quotation from a woman architect's interview: "Suppose that I love living in a triangle room, and I am imposing this on my client, saying, 'You should also live in a triangle room.' I am against this." The idea of not imposing one's own ideas on other people's lives was shared by other architects in this group. Participatory design, which was popular in the protest atmosphere of the 1970s in the West, became a desired goal in the design process, especially in the case of progressive architects. For example, an architect, who defined himself as a "contra architect," experimented with participatory design in his project for a housing cooperative. He made potential women engage in role playing, acting as if they were living in the model house built for this reason. He said, "Letting sisters and wives speak, letting them live the scenario as if they were cooking or going out to the balcony was really fun for them." He expressed strong feelings against architects' imposing their own ideas on users, saying, "We [he and his wife who run the office together] do not want to impose our own pyramids, towers, glass surfaces on other people. This is a requirement of democracy." Interestingly, the same architect, although he was against direct imposition of designs on users and clients, talked about guiding them toward a particular design outcome:

Our aim is never to give the feeling that the architect does it the way $\mathrm{s} /$ he wishes. Users are humans, and the nature has given them the basic instinct to know how to live. ... But you should provide your professional vision through tips and clues. For example, a man brings me a project and says that he wants something like that. I say, "Of course," but I don't follow that route. There are many other routes that I can go. It is very wrong to ruin his excitement. Not in terms of business, but it is not humane to do so. He has come up with an idea but he has not thought about it thoroughly. It is my duty to discuss it with him and to persuade him that his initial idea is wrong.

Another architect also experimented with participatory design in his project of cooperative housing in a village governed by a social democratic muhtar (the elected village head). He designed several alternatives, displayed them in the village hall, and asked potential users to choose among them. Some architects in this group liked the idea of dialogue between the architect and his/her client during the design process. However, this did not necessarily mean symmetrical relations between the two. For example, one of them said,

The ideal process of creating a space is the one in which there is collaboration between architects and users. For example, architects try to find clues about users' way of life and design a space in which people will do something new there, develop themselves, well, maybe not develop themselves but be happy, feel comfortable. But they should not use the space the way they used to do.

He continued,

When I design a house, I take 70 percent of the decisions, and I let them decide for 30 percent. We cannot decide 50-50, and this is not only because of the architectural knowledge I have accumulated over the years but also because of the knowledge I have gained about life in my experiences. Thus, in a way I decide for them

Flexibility in design emerged as another design principle used by architects to respond to the needs and 
preferences of users and clients. Yet paradoxically it could be seen as a problem by architects because it enabled people to change their living spaces as they wished, which could easily get out of control. A woman architect in her mid-forties and who holds a Ph.D. said, "The basic criterion for prototypical projects is flexibility because in the end everyone can shape the place they live in according to their preferences. However, when I saw the outcomes of this in my project, I came to doubt it, and I started asking whether it was appropriate for this society."

As seen in the preceding quotations, the architects in this third group argued for the need to be open to the preferences of their clients and users, grounding their argument in the discourse of democracy, and some of them experimented with participatory design practices. And, as such, they occupied a different position vis-à-vis their clients compared to those architects who designed according to the wishes of their clients because they had no other choice due to their economic dependency, or because they believed that it would not matter because clients would use the designed space as they wished anyway. However, similar to the architects in the other groups, these architects did not completely abandon the idea of changing people's lives through their designs. They did not regard themselves as merely using their expert knowledge to materialize the ideas and wishes of their clients. Instead, they wanted to make a difference, an "improvement," in the lives of their clients, and we might even say that they used participatory design as a (paternalistic) educational device, making people aware of something new, be it a new approach, a new way of interaction, or even a new way of life.

\section{Discussion}

A profession, by definition, means specialized (formal) knowledge, which brings professional authority. ${ }^{25}$ Professionals gain power and prestige by the expert knowledge and skills that they acquire in their training. ${ }^{26}$ As professionals, architects are entitled to authority in their designs. And this brings in the power dimension tilted in favor of the architect. On the other hand, this authority of the architect, which is based upon the claims of architecture as a profession, is open to challenges due to the particular characteristics of the profession ("the peculiarity of architecture"). ${ }^{27}$

Architecture as a profession is problematic on two grounds. First, architects use their professional knowledge and skills to shape other people's living spaces, and a deep ethical content is embedded in architectural work; secondly, architects lack enough scientific basis and specialization to legitimize their power claims. ${ }^{28}$ "Unlike the sciences, cultural areas as art and architecture cannot point to externalities to defend their judgments." ${ }^{29}$ As a result, challenges to architects are always ready to arise, both because people may not be willing to give to the architect the power to decide on their spaces, and because the architect may fail to support his/her ideas about a particular design with scientific facts. Turkish architects share this problem with their colleagues in other societies that emerge from the characteristics specific to their profession. On the other hand, the Turkish case, which has its roots in the specific nature of the formation of the Turkish republic as a modern nation, has certain features that further complicate the picture and increase the potential tensions and conflicts in the design process. The peculiar role given to the elites in the top-down modernization/Westernization of society in the recent history of the republic, and the social and cultural asymmetry it created between the modernizing elites and the masses, despite some changes over the years, seems to have prevailed today in the case of practicing architects in Ankara. Furthermore, the large number of rural migrants living in big cities, especially in Ankara where this field study was conducted, müteahhits who almost monopolized the construction sector until very recently, and the nouveau riche of recent times, who all, by their very definitions in society, lack cultural capital, have created a situation in which architects lean toward arrogance and patronization. ${ }^{30}$ The general claim of architects to being an authority on aesthetics and taste based on their professional training, when combined with their claim to "culture" in the Turkish context, has led to a tendency in architects to criticize clients for their lack of culture and taste (vulgarity) when clients' spatial practices and tastes diverge from theirs.

When we consider the attitudes of architects toward their clients and users in the field study, we see the claims to authority in their responses, yet to varying degrees. In their responses, again to varying degrees, we also see the traces of elitism, which refers to placing oneself above ordinary people and claiming to be the best (the most knowledgeable, the most cultured, and the like), and which hence implies paternalism. To different degrees, they tended to define themselves as superior to their clients in terms of "culture" (Bourdieu's distinction), and they tended to define their professional roles to include the responsibility to make a difference in people's lives through their designs and to guide them in the design process. ${ }^{31}$ These tendencies were sometimes overtly stated, and they were sometimes less pronounced, usually disguised in their claims to be responsive to clients. Sometimes they were strong, dominating architects' views and practices in the design process, and sometimes they existed in a dialectical relationship with the emerging tendencies toward a more equal distribution of power and status between the architect and the client. The first category of architects, who were mostly in their mid-sixties and all men, displayed patronizing attitudes and wanted to dictate their own terms in the design process, claiming to know what was good for others. On the other hand, the architects in the second category were cautious about displaying such a strong tendency of authority and superiority. Instead, they acknowledged the need to respond to their clients. Economic dependency was one reason, and another was their conviction that, whatever they did, clients would use their spaces as they wished. And, as a third reason, some mentioned democratic values and formed their discourses 
about the architect-client relationship on a democratic view, acknowledging people's rights to shape their own homes. They grounded the need for client responsiveness in the sine quo non of democracy. These architects were in their forties, both women and men. However, as seen in the quotations, their discourses were not free from the claims about the need of the architect to guide people's behavior by their designs. They implied benevolent reasons to do so, that is, to build better environments in which people would be able to improve themselves and would learn about new and better (modern) ways of life. However, this benevolence becomes problematic when architects perceive it as their right or responsibility to shape people's lives through their designs. This bears some resemblance to the modernist movement in the Western world, in which architects had the same concern to make better environments for people, yet they did not have any intention to consult users because "users did not know what they wanted, or more importantly, what they should have." ${ }^{32}$ As such, benevolence may change to paternalism and patronization; professional knowledge may move to arrogance.

We should be cautious not to overgeneralize the findings of the field study. The architects in the field study were those who graduated from universities in metropolitan cities and who run offices in Ankara, the capital city. Thus, their attitudes toward their clients may differ from those architects who graduated from Anatolian universities and who conduct their businesses in small towns. Moreover, the attitudes of recent graduates may be different from those of the older architects in the field study. No differences were found in the field study between women and men in the second category of architects regarding their approaches to their clients and users, whereas the first category of architects, who had claims to authority, were all men.

In brief, when we consider the architectural profession in the Turkish context, we can conclude that, although significant advances toward the democratization of the design process have taken place, it is still far from being satisfactory. When we compare those architects in the first category, most of whom were in their mid-sixties, to those architects in the second category, most of whom were in their mid-forties, we see improvements toward balancing the power between the architect and the client between the two generations. On the other hand, architects, at least those who run offices in Ankara, still tend to believe in the idea that they should make a difference in people's lives for the better, which implies intervention (that is, power). And yet this claim of theirs to power is increasingly contested as the society has become diversified and new client groups have emerged. Thus, architects' positions are formed between two poles: namely, the one that confers on architects power and authority based on the formal knowledge they have and on the social and political roles in society that are conditioned by its history, and the other one that challenges it in a changing society in which new social groups, values, and sources of power appear.

This article makes its theoretical contribution by emphasizing the importance of recognizing the social construction of architectural profession and architects' positions situated in the specificities of a particular society at a particular time period, and the power relations it embodies. By drawing attention to power in the design process and the contestation over it, this article maintains that professional ethics in architecture should be present on the academic agenda, and discussions on the question of who should decide what aspects in the design process should be kept alive. This is very important because, although the power of the architect may be challenged during the design process, once the design is converted into a built form, the power it has over people's lives is beyond dispute. Further research that investigates the social construction of architectural profession and the positions that architects take vis-à-vis their clients and users in different societies and in changing times would illuminate the power relationship between the architect and the client/user. Hence, it would be possible to identify those factors that prevent a more democratic relationship in the design process and develop suggestions to improve it.

\section{Acknowledgments}

The in-depth interviews were conducted by Burçak Altay, one of the coauthors of this article, in the winter of 2000 for her doctoral dissertation.

\section{Notes}

1. Denise Scott Brown, "Room at the Top?: Sexism and the Star System in Architecture," in Jane Rendell, Barbara Penner, and lain Borden, eds., Gender, Space, Architecture: An Interdisciplinary Introduction (London: Routledge, 2000), 261-62.

2. Magali S. Larson, Behind the Postmodern Façade: Architectural Change in Late-Twentieth Century America (Berkeley: University of California Press, 1993), 6

3. Ibid., 7 .

4. We use the term client to refer to those who commission the architect, whereas the term user to refer to those who are anonymous (such as potential residents of a mass housing project) or those who are present as a group (such as residents of a housing cooperative) during the design process.

5. Reşat Kasaba, "Kemalist Certainties and Modern Ambiguities," in Reşat Kasaba and Sibel Bozdoğan, eds., Rethinking Modernity and National Identity in Turkey (Seattle: University of Washington Press, 1997), 15-36

6. Sibel Bozdoğan, "The Predicament of Modernism in Turkish Architectural Culture," in Reşat Kasaba and Sibel Bozdoğan, eds., Rethinking Modernity and National Identity in Turkey (Seattle: University of Washington Press, 1997), 133-56

7. Zeki Sayar cited in Gülsüm Baydar Nalbantoğlu, "Silent Interruptions: Urban Encounters with Rural Turkey," in Kasaba and Bozdoğan, eds.,

Rethinking Modernity and National Identity in Turkey, 202.

8. Bozdoğan, “The Predicament of Modernism in Turkish Architectural Culture," 136-37.

9. Behçet and Bedrettin cited in Yeşilkaya, Halkevleri: Ideoloji ve Mimarlık (People's Houses: Ideology and Architecture), 114.

10. Bozdoğan, "The Predicament of Modernism in Turkish Architectural Culture," 138.

11. Behçet Ünsal cited in Yeşilkaya, Halkevleri, 116.

12. Yeşilkaya, Halkevleri, 119

13. The Turkish word salon refers to the best/biggest room of the residential unit, that is, Goffman's "front stage." See Erving Goffman, The Presentation of Self in Everyday Life (New York: Doubleday, 1959). 14. Bozdoğan, "The Predicament of Modernism in Turkish Architectural Culture," 139.

15. Ibid., 139

16. Illhan Tekeli, "The Social Context of the Development of Architecture in Turkey," in Renata Holod and Ahmet Evin, eds., Modern Turkish Architecture (Philadelphia: University of Pennyslvania Press, 1984), 26. 
17. Ayşe Öncü, "The Politics of the Urban Land Market in Turkey: 1950-1980," International Journal of Urban and Regional Research 12 (1988): 52-53.

18. Cengiz Bektaş, "Açık Oturum" (Open Session), Mimarlık 12 (1970): 38-39; and Önder Şenyapılı, "Türk Şehri" (the Turkish City), Mimarlık 3 (1968): 13-15.

19. Bozdoğan, "The Predicament of Modernism in Turkish Architectural Culture," 146.

20. Ibid., $146-47$

21. The Chamber of Architects is an organization legally authorized to protect the rights of the profession and to further its recognition in society and governmental bodies. It was legally established as the Chamber of Architects in 1954, following the previous efforts of the Architects' Association since 1928. The Chamber of Architects is the key organization that defines all legal norms and standards in architectura practice, and architects and architectural offices have to be enlisted as members to have the right to practice in Turkey. The Chamber of Architects has 21 branches, 79 representative offices, and 145 representatives in cities and towns all over Turkey. The Chamber also publishes the jour- nal Mimarlık (Architecture) a periodical distributed to its members. Since 1963, Mimarlık has been the main venue for architectural discussions. 22. Bozdoğan, "The Predicament of Modernism in Turkish Architectural Culture," 133 .

23. Tahire Erman, "The Politics of Squatter (Gecekondu) Studies in Turkey: The Changing Representations of Rural Migrants in the Academic Discourse," Urban Studies 38 (2001): 993-94.

24. All the interviews were conducted in the architectural offices of the respondents. The interviews lasted between 45 minutes to $1 \frac{1}{2}$ hours. They were tape recorded and later transcribed. The list of architectural offices in Ankara was obtained from the Chamber of Architects in the fall of 1999. From that list, another list was compiled by using those offices whose owners graduated before 1980. Those architects who graduated between 1965 and 1980 were chosen for the field study to ensure that respondents were established in architectural profession and had enough experience (at least twenty years in practice) to compare the professional practices and conditions of architects in Turkey. Becaus the number of women architects was much smaller than men architects (of those who run their own architectural offices in Ankara, 321 were women and 1,137 were men), a decision was made to spare one fourth of the sample for women architects, again randomly choosing them from the list.

25. Eliot Freidson, Professional Powers (Chicago: University of Chicago Press, 1986), 6

26. Judith R. Blau, Architects and Firms: A Sociological Perspective on Architectural Practice (Cambridge: The MIT Press, 1988), 6.

27. Larson, Behind the Postmodern Façade, 16

28. Blau, Architects and Firms, 6 .

29. Garry Stevens, The Favored Circle: The Social Foundations of Architectural Distinction (Cambridge: The MIT Press, 1998), 110.

30. Approximately 70 percent of Ankara's population lived in squatter housing in 1980. This number fell to 60 percent in 1995 as the result of the apartmentization of squatter neighborhoods through müteahhits [Ruşen Keleș, Kentleșme Politikası (The Policy of Urbanization) (Iıtanbul: !mge), 387]

31. For the analysis of architecture by Bourdieu's theory of distinction see Stevens, The Favored Circle, 31-113.

32. Ibid., 104. 